\title{
Teaching Writing Using Genre-Based Approach: a Study at a Vietnamese University
}

\author{
Thi Nhu Thuy Truong \\ Hue University College of Foreign Languages, Hue City, Vietnam
}

\begin{abstract}
This paper presents an exploratory study of using the genre-based approach in teaching a writing module focusing on writing letters for first-year English majors at a university in Vietnam. The aim of the study was to collect data from questionnaires and test results with a focus on learning the students' perceptions of this approach in learning the letter genre and what they benefitted from the most from this approach. The analysis reveals that under genre-based instruction the students' awareness and understanding of the features of the letter types were noticeably enhanced. The results indicate that for low-level learners organization of ideas, awareness of context and paralinguistic features were the issues they could gain control over upon the instructions. However, linguistic resources including grammar and vocabulary still remained problems that need a longer and more focused approach to develop. The findings also highlight the value of L1 background knowledge in learning writing in a foreign language.

Keywords: academic writing, genre-based instruction, Vietnam, Systemic Functional Linguistics
\end{abstract}

In learning a language, writing is considered the most difficult skill to achieve compared with speaking, listening and reading. In order to write successfully, a language learner needs not only the linguistic resources, but also the knowledge and understanding of the cultural differences. The learner's learning outcomes, to some extent, depends on the approach employed in the writing classroom. That places a demand on the teacher to choose an effective teaching approach. Currently, there are three approaches to teaching writing skills: product, process and genre-based approach. While the first one is no longer in favor, the latter two are still topics in the literature and research and the debate continues as to which is more effective. In practice, the choice of either approach is open to the teacher who can make the decision based on the learners' needs and the aims of the writing the course. However, to compare them, the genre-based approach has a more sound theoretical and pedagogical foundation supported with Systemic Functional Linguistics (SFL) by Halliday (1994) and sociocultural theories of learning by Vygotsky (1978). Since the 1980's the genre-based approach has become popular in ESL contexts. However, it has captured the interest of teachers in Asian non-English speaking countries like China, Japan, Indonesia, South Korea, and Thailand recently. The research results reported in those contexts suggest a positive effect

Language Education in Asia, 2017, 8(2), 192-212. http://dx.doi.org/10.5746/LEiA/17/V8/I2/A05/Truong 
of this approach on EFL learners' writing skills. In an attempt to find whether this approach was applicable to teach the writing skills for English majors, this paper was advocated to the use of this approach in the context of a university Vietnam.

\section{Genre-Based Approach}

\section{Literature Review}

Byram (2004) in The Routledge Encyclopedia of Language Teaching and Learning defines the genre-based approach as a framework for language instruction based on examples of a particular genre This approach emerged from SFL, first developed in Australia during the 1980 's. According to SFL, language is functional and through language we achieve certain goals. It emphasizes that language is used and understood within a context. With this underlying principle, the genre-based approach aims at enabling learners to write meaningful passages with framework support (Byram, 2004). It promotes explicit teaching of how to write different school genres (recount, narrative, report, essay, etc.) by offering a model of teaching that stresses explicit identification and teaching of the stages of a particular genre (Christie \& Unsworth, 2005). There are numerous definitions of what "genre" is. One of the first definitions of genre developed by Martin (1984) comes from SFL by Halliday (1978, 1985, 1994), who posits that genres are distinguished by choice of language suitable to the context in use to convey meaning successfully. Later, Swales (1990, p. 58) defines genre as "a class of communicative events, the members of which share some set of communicative purposes".

The genre-based approach supports learners to write with a very specific focus on vocabulary and grammar which characterize each type of genre, familiarizing them with the varying schematic structures. For example, the schematic structure of narratives (Martin \& Rothery, 1986) starts first with an orientation stage, then a complication stage and ends with a resolution stage. It may also be completed by a coda in which the writer expresses his or her own perspective on the story that has just been told. Further, Nunan (1999) emphasizes that genres have grammatical forms that reflect their communicative purpose; that is, each genre needs a particular language and grammar resource to realize the communication. The genrebased approach places the focus on the grammatical peculiarities of each genre, not on general grammar. For instance, the particular grammar of the narrative is the use of verbs of motion, feeling and thinking to describe a series of events and performers of actions; and that of adjuncts of time to show connections of actions across time. This approach also highlights that using the conventionalized knowledge of linguistic resources of each genre fosters successful achievement of a specific communicative purpose (Bhatia, 1993). The letter genre is an example that shows distinctive features in the conventional layout, tone and choice of language. A personal letter in English often conventionally starts with a greeting in a friendly tone to maintain good relationships, while a business letter is written in a formal tone and language to inform readers of specific information. It is also important to know that the organizations of these types of letters may bear differences from those in other languages.

\section{Genre-Based Instruction}

Genre-based instruction was first introduced in Australia and realized in the teaching-learning cycle which was first initiated by Callaghan and Rothery (1988). It includes three stages: Deconstruction, Joint Construction and Independent Construction. Later, Derewianka (1990), 
and Hammond and her colleagues (1992) further developed it into four recursive stages: Preparing or building knowledge of the field, Modelling of text, Joint-construction of the text and Independent construction of the text. Nunan and Lamb (1996) describes these four stages as follows. In the initial stage learners are provided with background content knowledge so that they can carry the task and achieve the goals. In the second stage, learners are introduced models with whole language in context. The teacher explicitly states the purpose of the modeled text, its generic structure and language features to foster an understanding of the language style and the social function of the genre. In the third stage, teacher and students work collaboratively to produce a text reduplicating the model. In the final one, learners work on their own independently to produce their texts. The teaching-learning cycle is "an interactive process of contextualization, analysis, discussion and joint negotiation of texts" (Hyland, 2002, p. 126).

In the context of Australia, the genre-based approach was initially used to develop students' literacy skills in writing and reading in the context of English as a first and second language. However, in the EFL context this approach is used to teach integrated language skills. It has captured the interest of EFL teachers and researchers in the recent decade. There are many studies which focus either on the students' perceptions of the GBA or the use of GBA to teach a particular genre (see e.g. Amogne, 2013; Chaisiri, 2010; Chen \& Su, 2012; Johns, 2011; Kongpetch, 2006; Liang, 2015; Viriya \& Wasanasomsithi , 2017; Wang, 2013; Watanabe 2016; Yasuda, 2011). For example, several research studies have been dedicated to the effectiveness of the genre-based approach on teaching argumentative essays in the EFL classrooms. Studies by Amogne (2013), Kongpetch (2006), Luu (2011), Promwinai (2010), Trinh \& Nguyen (2014) provide evidence of learner improvement in relation to the essay features including organization, argument logic, thesis construction and language. Different research by Chen and Su (2012), Luu (2011), Tuyen et al. (2016), Yasuda (2011) Wang (2013), Watanabe (2016) and Viriya and Wasanasomsithi (2017) report the learners' progress on summary writing, writing recount genre, research papers, email-writing, apology letters, exposition essays and enhancement of writing ability, respectively. These research findings reveal that most of the learners gained control over the key features of the target genre in terms of social purposes, language features and organization.

Compared with the product approach and process approach, the genre-based approach is relatively new. However, it provides new perspectives on teaching writing which are distinguished from the previous approaches with the clear focus on and explanation of the genre features and functions. The genre-based approach also facilitates clear links between learning in the classroom and the writing beyond it (Lin, 2006). Some proponents of the genrebased approach suggest the combination of this approach either with the product approach (Dudley-Evan \& St. John, 1998) or with the process approach (Badger \& White, 2000) to make use of the strengths of all these approaches. The choice depends on the teacher in each context of teaching. However, it could be stressed that what differentiates the genre-based approach from the others is the advocacy that language is functional and the choice of language and grammar is determined by the context, purpose and audience. Since its development, the genre-based approach has now become influential in the field of language 
teaching (Derewianka, 2003) and one of the major trends in the new millennium (Richards \& Rodgers, 2014).

Despite its popularity in L1 and L2 context since 1980's, the genre-based approach remains a fresh topic for the EFL context. In Luu's (2011) opinion, Vietnamese teachers endeavor to examine the effect of the genre-based approach on students' writing performance and attitudes towards the implementation of this approach in learning writing. The positive reports of the use of this approach in EFL writing classes have encouraged the researcher to continue investigating its application to teaching writing the letter genre as a university writing module for Vietnamese English-majored students.

\section{Context and Participants}

\section{Methodology}

The national context of the current study is Vietnam. In Vietnam, before being admitted to university, students must sit and pass the national exams, which are inclusive of an English test. The English test is norm-referenced and is scored on a 0-10 band range. The results of the test impact on students in the sense that they have an increased chance of gaining admission to university the higher their band score is. It is also important to note that in 2008, the Vietnam Ministry of Education and Training officially adopted the Common European Framework of Reference (CEFR) as the national framework of reference for English education in Vietnam.

The specific participants in the current study had emerged from this Vietnamese educational context. Sixty participants were invited to participate in the study, all of whom had passed the English test, and were of A2 proficiency with regard to the CEFR, as this is the minimum required level for freshmen in the Vietnamese context. The students were enrolled in the writing course of the first-year majors, in their first semester of university, and were spread across two classes (30 students in each class). Like many first-year Vietnamese university students, the participants had learned English as a school subject and had not been instructed in any formal writing course before. As university English majors, the participants would study English for four years to use English professionally to work as English teachers, tour guides, translators, interpreters or office workers. The demographic information of the participants can be seen below in the Table below.

\section{Demographic Information of Participants}

\begin{tabular}{|l|l|l|l|l|l|}
\hline Number & \multicolumn{2}{|l|}{ Gender } & Age & Level & $\begin{array}{l}\text { Level expected to achieve after } \\
\text { the first year }\end{array}$ \\
\hline 60 & $\begin{array}{l}\text { Females } \\
43\end{array}$ & $\begin{array}{l}\text { Males } \\
17\end{array}$ & $18-21$ & A2 of CEFR & B1 of CEFR \\
\hline
\end{tabular}

The sampling approach adopted in the study adheres to what is commonly referred to as "nonprobability" sampling, and specifically "purposive sampling". Purposive sampling is in alignment with the goals of qualitative research projects where the overarching aim is generally to "describe the aspects of an idiosyncratic experience rather than determining the most likely, or mean experience, within a group" (Dörnyei, 2007, p. 126). Within an overarching, purposive approach to selecting the sample, a more specific strategy of "typical sampling" was 
adopted. With regard to the overarching purposive approach, it was necessary to make decisions about who the participants would be. Within this study, the participants needed to be students of a writing course within the Vietnamese context, for the purpose of focusing on the genre-based approach. In relation to the "typical sampling" strategy, the participants were chosen based on the fact that their experiences was typical in terms of the focus of the research. Dörnyei (2007) explains that while it is not immediately possible for the experiences of the sample to be generalized, it is possible to establish certain typical features which could bear similarities to other similar contexts within Vietnam, as is the case in this study.

The study was implemented over one 15-week semester for Writing 1 Course. This was the first in five compulsory writing courses named from Writing 1 to Writing 5 English majors had to attend at university. Each course was 100 -minute lesson a week. In Writing 1, the participants learned how to write different types of letter, which include writing a response to an invitation, writing a response giving advice, writing a complaint letter, writing an opinion letter and writing a letter to editor.

The researcher was the course instructor of the participants. The instruction used in the class was the genre-based instruction (GBI). The choice of this instruction was argued as follows:

- The genre-based approach (GBA) provides a systematic explanation how such texts are organized in different social and cultural contexts (Hyland, 2003).

- GBA suggests explicit instruction and intervention from the teacher in class (Hyland, 2003).

- The genre-based instruction (GBI) allows the teacher to provide learners with scaffolding at any stage in the teaching-learning cycle (Vygotsky, 1978).

\section{Data Collection and Procedure}

In order to collect data for the study, the following sets of questionnaires were used:

Preliminary questionnaires. These were delivered to the students at the beginning of the course to find whether they were accustomed to writing the various letter types in the mother tongue as school assignments and/or in their daily communication (Appendix A).

Primary Questionnaires - these were repeatedly delivered to them to record their responses to the effect of the four stages of the genre-based instructions used in the class after they finished learning a letter type. This set of questionnaires included the questions to ask for the participants' opinions about the effects of stage 1 to stage 3 of the teaching-learning cycle; and the questions for stage 4 served as a final draft checklist for them to answer when they practiced writing at home (Appendix B)

Post-questionnaires. These were delivered to the students at the end of the course to have their feedback on their improvement of writing the letter genre (Appendix C).

The participants were asked to give their responses every two weeks after they finished learning a different letter type. The answers were counted and analyzed by constructing frequency and percentage distribution tables based on the items in the questionnaires. 
In addition, there were two writing tests administered after the first three types of letter and after the last one were taught to measure the students' progress (Appendix D). The tests were modified from Part II and III of the Cambridge B1 proficiency Test -Preliminary English Test (PET). Regarding the difficulty of the tasks, topics were selected so as to enhance the participants' background knowledge of current and familiar issues. The students' papers were assessed based on the use of letter conventions, understanding of the test requirements, organization of ideas and the choice of proper language resource. The test results were tabulated from the highest scores to the lowest with corresponding grades according to Vietnam's grading system at university.

In order to ascertain the impact of genre-based instruction on the participants in the study, the following research questions were developed:

1. What are the students' perceptions of the effect of the genre-based instruction in learning the letter genre?

2. What features of the genre letter do they benefit from the most under the genre-based instruction?

\section{Findings}

The following details the findings in relation to the research questions that guided the study.

\section{Students' Letter Writing Skills in L1}

The results displayed in Tables A1 and A2 show the familiarity of the participants with the letter genre in their mother tongue (see Appendix A for the questionnaire). Table A1 shows $71.6 \%$ and $58.3 \%$ of them had experienced writing a response to an invitation (type A) and a response giving advice (type $\mathrm{B}$ ). However, it records that no one had ever had experience with types $C$ (complaint letter), D (opinion letter) and $\mathrm{E}$ (letter to editor). Table A2 also reveals that the respondents wrote letters of types $A$ and $B$ only in informal situations, such as writing to their friends or relatives.

\section{Table A1}

\section{Types of Letter Genre Students Wrote in L1}

\begin{tabular}{|l|l|l|l|}
\hline \multicolumn{2}{|l|}{ Types of letter genre } & $\mathrm{n}=60$ & Percent \\
\hline Type A & Writing a response to an invitation & 43 & 71.6 \\
\hline Type B & Writing a response giving advice & 35 & 58.3 \\
\hline Type C & Writing a complaint letter & 0 & 0 \\
\hline Type D & Writing an opinion letter & 0 & 0 \\
\hline Type E & Writing a letter to editor & 0 & 0 \\
\hline
\end{tabular}




\section{Table A2}

Situations Students Wrote Letter Type A and Type B in L1

\begin{tabular}{|c|c|c|c|c|}
\hline \multirow{2}{*}{\multicolumn{3}{|c|}{ Types of letter genre }} & \multicolumn{2}{|c|}{ Situations } \\
\hline & & & Informal & Formal \\
\hline Type A & Writing a response to an invitation & & $\begin{array}{l}43 \\
100 \% \\
\end{array}$ & $\begin{array}{l}0 \\
0\end{array}$ \\
\hline Type B & Writing a response giving advice & $n=60$ & $\begin{array}{l}35 \\
100 \%\end{array}$ & $\begin{array}{l}0 \\
0\end{array}$ \\
\hline
\end{tabular}

\section{Students' Perceptions of the Effect of the Teaching-Learning Cycle (TLC) in Learning the Letter Genre}

In this section, the participants' responses to the four stages of the TLC under investigation are presented (see Appendix B for the questionnaire).

\section{Table B1}

Students' responses to Preparing or Building Knowledge of the Field

\begin{tabular}{|c|c|c|c|c|}
\hline & $\begin{array}{l}\text { Very } \\
\text { helpful }\end{array}$ & Helpful & $\begin{array}{l}\text { Not } \\
\text { much }\end{array}$ & $\begin{array}{l}\text { Not at } \\
\text { all }\end{array}$ \\
\hline 1. Raising the awareness of the letter type & $\begin{array}{ll}28 \\
46.7 \%\end{array}$ & $\begin{array}{l}32 \\
53.3 \%\end{array}$ & $\begin{array}{l}0 \\
0 \%\end{array}$ & $\begin{array}{ll}0 \\
0 \%\end{array}$ \\
\hline 2. Raising the awareness of the format of the letter & $\begin{array}{l}25 \\
41.7 \%\end{array}$ & $\begin{array}{l}33 \\
55 \%\end{array}$ & $\begin{array}{l}2 \\
3.3 \%\end{array}$ & $\begin{array}{l}0 \% \\
0 \%\end{array}$ \\
\hline 3. Raising the awareness of the intended readers of the letter & $\begin{array}{l}22 \\
36.7 \%\end{array}$ & $\begin{array}{l}38 \\
63.3 \%\end{array}$ & $\begin{array}{l}0 \\
0 \% \\
\end{array}$ & $\begin{array}{l}0 \\
0 \%\end{array}$ \\
\hline 4. Raising the awareness of the purpose of the letter & $\begin{array}{l}27 \\
45 \%\end{array}$ & $\begin{array}{l}32 \\
53.3 \%\end{array}$ & $1.7 \%$ & $\begin{array}{ll}0 \\
0 \%\end{array}$ \\
\hline 5. Raising the awareness of the context of the letter & $\begin{array}{l}17 \\
28.3 \%\end{array}$ & $\begin{array}{l}38 \\
63.3 \%\end{array}$ & $\begin{array}{l}5 \\
8.3 \%\end{array}$ & $\begin{array}{l}0 \\
0 \%\end{array}$ \\
\hline $\begin{array}{l}\text { 6. Raising the awareness of the culture-specific features of the } \\
\text { letter }\end{array}$ & $\begin{array}{l}19 \\
31.7 \%\end{array}$ & $\begin{array}{l}33 \\
55 \%\end{array}$ & $\begin{array}{l}7 \\
11.7 \%\end{array}$ & $\begin{array}{l}1 \\
1.7 \%\end{array}$ \\
\hline
\end{tabular}

Table B1 reports the participants' average responses to the first stage in leaning all the letter types. The question items focused on finding whether it enhanced their awareness of the paralinguistic features (items 1-2), the contextual features (items 3-5) and the culture-specific feature (item 6) of the five letter types. For all the items, the results show positive answers with more than 90 percent agreeing that this stage was either very useful or useful. The negative responses ranging from $1.7 \%$ to $11.7 \%$ fell into items $4-6$. 


\section{Table B2}

Students' Responses toward Modelling of Text

\begin{tabular}{|l|c|c|c|c|c|}
\hline & Type A & Type B & Type C & Type D & Type E \\
\hline 1. Recognizing the format of the model letter & 60 & 57 & 57 & 59 & 59 \\
& $100 \%$ & $95 \%$ & $95 \%$ & $98.3 \%$ & $98.3 \%$ \\
\hline $\begin{array}{l}\text { 2. Aware of the writer and the intended } \\
\text { audience of the model letter }\end{array}$ & 60 & 56 & 55 & 53 & 57 \\
\hline 3. Distinguishing the tone of the model letter & $57 \%$ & $93.3 \%$ & $91.7 \%$ & $88.3 \%$ & $95 \%$ \\
\hline $\begin{array}{l}\text { 4. Recognizing how ideas are organized in } \\
\text { the model letter }\end{array}$ & 57 & 51 & 40 & 40 & 40 \\
\hline $\begin{array}{l}\text { 5. Able to pick up the language features of the } \\
\text { model letter }\end{array}$ & 50 & $85 \%$ & $78.3 \%$ & $68.3 \%$ & $75 \%$ \\
\hline
\end{tabular}

Table B2 presents the findings whether the participants were able to recognize the paralinguistic features (items $1 \& 3$ ), the context of the letter type (item 2), the organization of ideas (item 4) and the language features (item 5) of the modelled texts. Among the items, the responses to items $1-2$ were very high for all the letter types. This was confirmed with the data of items 1, 2 and 3 in Table B1. With item 3, the highest response was for letter types A and B, while the remaining received equally lower replies. This finding coincided with the data in Table A1 and Table A2, which show the students' familiarity with types A and B in their mother tongue. With items 4 and 5, type $D$ had the lowest number of selectors.

\section{Table B3}

\section{Students' Responses toward Joint-construction of the Text}

\begin{tabular}{|c|c|c|c|c|c|}
\hline & Type A & Type B & Type C & Type D & Type E \\
\hline $\begin{array}{l}\text { 1. = Fostering understanding of features of } \\
\text { the letter type }\end{array}$ & $\begin{array}{c}56 \\
93.3 \%\end{array}$ & $\begin{array}{c}50 \\
83.3 \%\end{array}$ & $\begin{array}{c}47 \\
78.3 \%\end{array}$ & $\begin{array}{c}53 \\
88.3 \%\end{array}$ & $\begin{array}{c}49 \\
81.6 \%\end{array}$ \\
\hline 2. Enabling joining writing practice & $\begin{array}{c}55 \\
91.6 \%\end{array}$ & $\begin{array}{c}45 \\
75 \%\end{array}$ & $\begin{array}{c}39 \\
65 \%\end{array}$ & $\begin{array}{c}38 \\
63.3 \%\end{array}$ & $\begin{array}{c}33 \\
55 \%\end{array}$ \\
\hline 3. Providing useful feedback from the teacher & $\begin{array}{l}51 \\
85 \%\end{array}$ & $\begin{array}{c}50 \\
83.3 \%\end{array}$ & $\begin{array}{c}45 \\
75 \%\end{array}$ & $\begin{array}{c}43 \\
71.6\end{array}$ & $\begin{array}{c}44 \\
73.3 \%\end{array}$ \\
\hline $\begin{array}{l}\text { 4. Building up confidence for individual writing } \\
\text { in stage } 4\end{array}$ & $\begin{array}{c}51 \\
83.3 \%\end{array}$ & $\begin{array}{c}50 \\
83.3 \%\end{array}$ & $\begin{array}{c}37 \\
61.7 \%\end{array}$ & $\begin{array}{c}32 \\
53.3 \%\end{array}$ & $\begin{array}{c}40 \\
66.6 \%\end{array}$ \\
\hline
\end{tabular}

Table B3 shows the majority of the students agreed with item 1 for all types, which indicates group works could further develop their understanding of what they learned in the previous stages. With the remaining items, high responses were recorded with letter types A and B. However, the positive answers went down with other types. For item 5, the proportions again decreased by around one thirds for the last three types of letters. 


\section{Table B4}

Students' Responses toward Independent Construction of the Text

\begin{tabular}{|c|c|c|c|c|c|}
\hline & Type A & Type B & Type C & Type D & Type E \\
\hline $\begin{array}{l}\text { 1. Understanding the requirements of the } \\
\text { writing task }\end{array}$ & $\begin{array}{l}60 \\
100 \% \\
\end{array}$ & $\begin{array}{l}60 \\
100 \% \\
\end{array}$ & $\begin{array}{l}60 \\
100 \% \\
\end{array}$ & $\begin{array}{l}60 \\
100 \% \\
\end{array}$ & $\begin{array}{l}60 \\
100 \% \\
\end{array}$ \\
\hline 2. Aware of the intended reader & $\begin{array}{l}60 \\
100 \% \\
\end{array}$ & $\begin{array}{l}60 \\
100 \% \\
\end{array}$ & $\begin{array}{ll}60 \\
100 \% \\
\end{array}$ & $\begin{array}{ll}60 \\
100 \% \\
\end{array}$ & $\begin{array}{l}60 \\
100 \% \\
\end{array}$ \\
\hline 3. Able to use the conventional format & $\begin{array}{l}50 \\
91.6 \%\end{array}$ & $\begin{array}{l}51 \\
85 \%\end{array}$ & $\begin{array}{l}49 \\
78.3 \%\end{array}$ & $\begin{array}{l}47 \\
76.7 \%\end{array}$ & $\begin{array}{l}47 \\
76.7 \%\end{array}$ \\
\hline 4. Choosing the right tone for the letter & $\begin{array}{l}51 \\
85 \% \\
\end{array}$ & $\begin{array}{l}45 \\
75 \% \\
\end{array}$ & $\begin{array}{l}34 \\
56.7 \% \\
\end{array}$ & $\begin{array}{l}33 \\
55 \% \\
\end{array}$ & $\begin{array}{l}33 \\
55 \% \\
\end{array}$ \\
\hline 5. Considering the cultural context & $\begin{array}{ll}56 \\
93.3 \%\end{array}$ & $\begin{array}{ll}53 \\
88.3 \%\end{array}$ & $\begin{array}{l}55 \\
91.6 \% \\
\end{array}$ & $\begin{array}{ll}55 \\
91.6 \%\end{array}$ & $\begin{array}{ll}53 \\
88.3 \%\end{array}$ \\
\hline 6. Paying attention to organization & $\begin{array}{l}60 \\
100 \%\end{array}$ & $\begin{array}{l}60 \\
100 \%\end{array}$ & $\begin{array}{l}60 \\
100 \%\end{array}$ & $\begin{array}{l}60 \\
100 \%\end{array}$ & $\begin{array}{l}60 \\
100 \%\end{array}$ \\
\hline $\begin{array}{l}\text { 7. Choosing language resource suitable for } \\
\text { the context }\end{array}$ & $\begin{array}{l}44 \\
73.3 \% \\
\end{array}$ & $\begin{array}{l}41 \\
68.3 \% \\
\end{array}$ & $\begin{array}{l}27 \\
45 \% \\
\end{array}$ & $\begin{array}{l}26 \\
43.3 \% \\
\end{array}$ & $\begin{array}{ll}31 \\
51.7 \%\end{array}$ \\
\hline
\end{tabular}

As presented in Table B4, all the participants gave positive answers to items 1, 2 and 6, which reminded them of the purpose of the letter, the addressee and the organization of ideas. The next three items 3, 4 and 5 were closely related to each other. Compared with the positive answers to types $A$ and $B$, those to item 4 were much lower for letters of types $C, D$ and $E$. Similarly, more than half of negative replies were recorded for letters of types $C$ and $D$ for the last item.

\section{Students' Improvements under the Use of Genre-Based Instruction}

\section{Table C1}

\section{Students' Responses to their Improvements under $G B I$}

\begin{tabular}{|l|l|l|}
\hline Features & $\mathrm{n}=60$ & Percentage \\
\hline 1. Organization & 57 & $95 \%$ \\
\hline 2. Context & 51 & $85 \%$ \\
\hline 3. Conventions & 48 & $80 \%$ \\
\hline 4. Tone & 48 & $80 \%$ \\
\hline 5. Grammar & 41 & $68 \%$ \\
\hline 6. Vocabulary & 37 & $62 \%$ \\
\hline
\end{tabular}

Table C1 (see Appendix C for the post-questionnaire) summarizes the features of the letter genre the participants claimed to have experienced improvement in. The data is arranged from the highest to the lowest. 


\section{Table C2}

Types of Letter Genre Students Able to Write Successfully

\begin{tabular}{|l|l|l|l|}
\hline \multicolumn{2}{|c|}{ Types of letter genre } & \multicolumn{1}{c|}{$\mathrm{n=60}$} & \multicolumn{1}{c|}{ Percent } \\
\hline Type A & Writing a response to an invitation & 51 & $85 \%$ \\
\hline Type B & Writing a response giving advice & 45 & $76.7 \%$ \\
\hline Type E & Writing a letter to editor & 37 & $62 \%$ \\
\hline Type C & Writing a complaint letter & 33 & $55 \%$ \\
\hline Type D & Writing an opinion letter & 29 & $48.3 \%$ \\
\hline
\end{tabular}

Table C2 displays the students' feedback on the types of letter genre they felt confident to write after learning (see Appendix C). The data is arranged from the letter type with the highest percentage to the one receiving the lowest percentage.

\section{Table D}

Students' Test Results

\begin{tabular}{|c|c|c|c|c|c|}
\hline \multirow[b]{2}{*}{ Tests } & \multicolumn{5}{|c|}{ Mark Results } \\
\hline & $\begin{array}{c}8.5 \text { and above } \\
\text { A }\end{array}$ & $\begin{array}{c}7.0 \text { to } 8.4 \\
\text { B }\end{array}$ & $\begin{array}{c}5.5 \text { to } 6.9 \\
\text { C }\end{array}$ & $\begin{array}{c}4.0 \text { to } 5.4 \\
\text { D }\end{array}$ & $\begin{array}{c}\text { Under } 4.0 \\
\mathrm{~F}\end{array}$ \\
\hline Test 1 & $\begin{array}{l}7 \\
11.7 \% \\
\end{array}$ & $\begin{array}{l}24 \\
40 \% \\
\end{array}$ & $\begin{array}{l}23 \\
38.3 \% \\
\end{array}$ & $\begin{array}{l}6 \\
10 \% \\
\end{array}$ & $\begin{array}{l}0 \\
0 \% \\
\end{array}$ \\
\hline Test 2 & $\begin{array}{l}5 \\
8.3 \%\end{array}$ & $\begin{array}{l}27 \\
45 \%\end{array}$ & $\begin{array}{l}25 \\
41.7 \%\end{array}$ & $\begin{array}{l}3 \\
5 \%\end{array}$ & $\begin{array}{l}0 \\
0 \%\end{array}$ \\
\hline
\end{tabular}

The two tests (see Appendix D) examined the students' skills of writing the letters they learned. They aimed to link learning in the classroom and the communication beyond it (Lin, 2006). The participants' letters were marked based on the items as criteria shown in Table C1. Table D presents the students' marks based on 10 grade points and the corresponding letter grades $A$, $\mathrm{B}, \mathrm{C}, \mathrm{D}$ and $\mathrm{F}$. While A grades went down in the second test, $\mathrm{D}$ grades seemed improved. The numbers of $\mathrm{D}$ grades and $\mathrm{C}$ grades combined did not much fluctuate in the two tests.

\section{Discussion}

The data analysis of this research revealed two key findings. The first was that the GBI increased their awareness and understanding of the features of the letter genre. The second was the noticeable improvements that the low-level learners claimed to have gained under this instruction. The follow sections will address the specific research questions of the study to highlight what has been learned.

\section{Research Question 1}

It is widely recognized that the local text structures within a text type often have differences across cultures. In this case, the letter types in Vietnamese do not resemble those in English in many aspects. The use of GBI aimed at enhancing the participants' perception of the differences and raised their awareness of the distinctive features, especially for the letter types they were not familiar with. As the students had not experienced writing formal letters in their L1, the explicit genre-based teaching, for example, was able to help them quickly identify the differences in the layout and the structure of an English formal letter. The results from Table B1 
to Table B4 indicate the learner's perception of the importance of the questions and issues used to orientate the learners to the social context and the communicative purpose of each letter type. The aspects which received the most approval from the participants relate to the context, format, conventions and the organization to make the letters accepted in the culture of the target language. This is in alignment with Hyland's (2003, p. 27) belief that learning writing is best achieved "through explicit awareness of language", "with a sense of self, of others, of situation, of purpose". Similarly, Hammond et al (1992) emphasizes that assisting learners to gain an understanding of a context is essential in genre-based writing.

In view of the participants' responses to the effect of GBI on learning different letter types, the results were not the same. Their positive responses to letter types A and B may indicate the connection of L1 knowledge with the target genre in L2. Results from acquisition research supports that languages can promote each other's development reciprocally and that a foreign language learner must build upon existing skills and knowledge acquired in and through the mother tongue (Butzkamm, 2003). The background knowledge and skills in L1 enabled the participants to acquire the first two types of letters more effectively. Though the participants underwent the same stages of instruction in learning all the letter types, they encountered more

difficulty with the features of the formal letters of types C, D and E (see Table B4). Despite their claim of improved awareness of the conventions and cultural context of these letters, around half of the participants admitted having problems with the tone and language resource characterizing the formal style. Their problems were almost certainly the result of their unfamiliarity and lack of exposure to these types of letters. This links with Hammond et al (1992)'s view that in order to learn to write effectively students first need to have an extensive understanding of and familiarity with the topic they are writing about in the preparing stage. This suggests the teachers' more attention and scaffolding given to the students in teaching them the skills that they have no experience in their L1.

\section{Research Question 2}

As shown in the Table C1, the most noticeable improvements the participants claimed to have achieved were the organization and understanding of the context. Research by Wang (2013) supports this idea by emphasizing that most of the participants report progress after the genre instruction on the rather surface-level aspects, such as proper salutation and complimentary closure, layout of the letter, and degree of formality in vocabularies. Table C1 indicates approximately one thirds of the participants reported not having improvements with grammar and vocabulary. These results were consistent with findings by Kongpetch (2006) and Trinh \& Nguyen (2014) that students showed improvement of the text organization, audience awareness and purpose, but not the language itself. This is supported with a study on the students' email writing ability by Yasuda (2011) that though the students showed significant improvement with cohesion and organization, grammatical control, they did not show much student improvements on vocabulary size. That means the control over the language features practically requires more time and to tackle. With this finding the researcher believes that the GBI which was implemented only for 30-hour class time could not bring about much significant change in the language resource for the participants. 
The feedback the participants gave in Table C2 again confirms the value of L1 knowledge in enhancing their learning of the letter types in L2 with more than $75 \%$ felt able to write successfully with types A and B. The findings match with the researcher's anticipation that the students tended to feel more confident with the letter type they had experienced in L1. Nonetheless, more than half of the participants were not able to successfully write letter type D, opinion letters. Compared with the data on Tables 1-4, this type received nearly all the lowest responses among the five types. There are many reasons for their problems, of which the obvious ones can be how to make their points clear and persuasive with the use of proper grammar and vocabulary in a formal tone and style.

In the mid-test and post-test, the task requirements examined the skills they learned in the course. The topics were chosen to link the background knowledge of current and familiar issues. They aimed to link learning in the classroom and the communication beyond it as mentioned by Lin (2006). Regarding to the results, though there was not much fluctuation of grades $B$ and $C$ combined, the mid-test had more grades $A(11.7 \%)$ and $D(10 \%)$ compared with the post-test. As the first test required the students to write the letter types they were familiar in L1, to some extent it increased their chance of having good grades. However, $10 \%$ of the students with $\mathrm{D}$ grades also indicated that the GBI was not as effective as expected for a small group of students at the first time when the instruction was implemented. In the post-test, both $\mathrm{A}$ and $\mathrm{D}$ grades fell down (8.3\% and 5\%, respectively). The decrease of A grades indicates the difficulty of the letter types as the students revealed in Table C2. However, the decrease of D grades shows the students' improvement under GBI.

\section{Limitations}

This study has some limitations. Firstly, it employed purposive sampling. This fact may give rise to the question of the validity of the methodology, design and data collection of the study. With a limited number of 60 participants, the results were not intended to give a generalization beyond the context of the study but rather to report an application of the instruction in a particular context in which this instruction had not been used before. Secondly, the data was collected by means of the questionnaires and test results within a short period of time of the class hours. Thirdly, the subject of the study focused on a micro genre, the letter genre, namely five types of the letters the participants learned in their first writing modules at university. The results need more support from in-depth research on the learning results in the tests of language competence of a larger population to confirm these findings and further explore the full potential of the approach. Further longitudinal research can be developed to observe the effectiveness of the genre-based approach on teaching other genres with learners of other language levels. A topic that may draw from this research is the role of background knowledge in L1 in promoting the genre awareness and language competence for EFL learners.

\section{Conclusion}

This is an action research in an educational setting with the aim to examine the writing classroom under the genre-based instruction. It was conducted among low-intermediate level participants in learning writing letters. The results suggest that the instruction had positive effects on the participants in learning letter writing thanks to the explicit teaching of the 
purpose, audience, social context, the language and structure of a particular genre. After 30 hours of classroom time, the features that showed the participants' most improvements were the awareness of the context, the choice of appropriate conventions, the organization of ideas and the paralinguistic features. However, the progress in the language resource, i.e. grammar and vocabulary was not as high as other features. The results indicate that learners need a longterm instruction under this approach so as to make improvements with the language features in their writing skills. 


\section{Author Note}

Author information: Thi Nhu Thuy Truong, English Department, Hue University College of Foreign Languages, Hue City, Vietnam.

Biodata:

Thi Nhu Thuy Truong is a lecturer from the English Department, Hue University College of Foreign Languages, Vietnam. She is responsible for delivering English language skills, grammar and discourse analysis courses. Thuy holds a Master's degree in Education, majoring in TESOL. Her professional interests include applied linguistics and teaching language skills.

Contact information: Thi Nhu Thuy Truong, English Department, Hue University College of Foreign Languages, 57 Nguyen Khoa Chiem St., Hue City, Vietnam.

E-mail: nhuthuytt@yahoo.com 


\section{References}

Amogne, D. (2013). Enhancing students' writing skills through the genre approach. International Journal of English and Literature, 4(5), 242-248.

Badger, R., White, G. (2000). A process genre approach to teaching writing. ELT Journal, 54(2), 153-160. https://doi.org/10.1093/elt/54.2.153

Bhatia, V. K., (1993). Analysing genre: Language use in professional settings. London: Longman.

Butzkamm, W. (2003). We only learn language once. The role of the mother tongue in FL classrooms: Death of a dogma. Language Learning Journal, 28, 29-39. http://dx.doi.org/10.1080/09571730385200181

Byram, M. (2004). Genre and genre-based teaching. In M. Byram \& A. Hu (Eds.), The Routledge encyclopedia of language teaching and learning (pp. 234-237). London: Routledge.

Callaghan, M. \& Rothery, J. (1988). Teaching factual writing (Report of the DSP literacy project, Metropolitan East Region), NSW Department of Education, Sydney.

Chaisiri, T. (2010). Implementing a genre pedagogy to the teaching of writing in a university context in Thailand. Language Education / n Asia, 1, 181-199. https://doi.org/10.5746/LEiA/10/V1/A16/Chaisiri

Chen, S. \& Su, S. (2012). A genre-based approach to teaching EFL summary writing. ELT Journal, 66(2), 184-192. http://dx.doi.org/10.1093/elt/ccr061

Christie, F., \& Unsworth, L. (2005). Developing dimensions of an educational linguistics. In J. Webster, C. Matthiessen, \& R. Hasan (Eds), Continuing discourse on language: $A$ functional perspective (pp. 217-250). London: Equinox

Derewianka, B. (1990). Exploring how texts work. PETA, Sydney.

Derewianka, B. (2003). Trends and issues in genre based approach. RELC Journal, 34 (2), 133-154.

Dörnyei, Z. (2007). Research methods in applied liguistics. Oxford : Oxford University Press.

Dudley-Evan, T. \& St. John, M. (1998). Developments in English for specific purposes. www.aelfe.org/documents/text2-Palmer.pd

Halliday, M. A. K. (1985). Introduction to functional grammar, London: Edward Arnold.

Halliday, M. A. K. (1994). An introduction to functional grammar(2nd ed.). London: Edward Arnold.

Halliday, M.A.K. (1978). Language as social semiotic: The social interpretation of language and meaning. London: Edward Arnold.

Hammond, J., Burns, A., Joyce, H., Brosnan, D., Gerot, L., Solomon, N., \& Hood, S. (1992). English for social purposes: A handbook for teachers of adult literacy. Sydney: National Centre for English Language Teaching and Research, Macquarie University.

Hyland, K. (2002). Genre: Language, context, and literacy. Annual Review of Applied Linguistics, 22, 113-135. http://dx.doi.org/10.1017/S0267190502000065

Hyland, K. (2003). Genre-based pedagogies: A social response to process. Journal of Second Language Writing, 12(2003), 17-29. http://dx.doi.org/10.1016/S1060-3743(02)00124-8

Johns, A. (2011). The future of genre in L2 writing: Fundamental, but contested, instructional decisions. Journal of Second Language Writing, 20(2011), 56-68.

http://dx.doi.org/10.1016/j.jslw.2010.12.003 
Kongpetch, S. (2006). Using a genre-based approach to teaching writing to Thai Student: A case to study. Prospect. 21(2), 3- 33.

Liang, E. (2015). Implementing genre-based curriculum cycle in teaching writing in a secondary school setting. Studies in Literature and Language, 10 (1), 47-50.

Lin, B. (2006). Vygotskian principles in the genre-based approach to teaching writing. NUCB JLCC, 8(3), $1-15$.

http://ci.nii.ac.jp/els/contentscinii_20170621175543.pdf?id=ART0008045057

Luu, T. T. (2011). Teaching writing through genre-based approach. Brazilian English Language Teaching Journal, 2(1), 121-136. http://revistaseletronicas.pucrs.br/ojs/index.php/belt/article/view/9361

Martin, J. R. (1984). Language, register and genre. In F. Christie (Ed.), Children writing: Reader 21-29. Geelong: Deakin University Press.

Martin, J. R. \& Rothery, J. (1986). What a functional approach to the writing task can show teachers about "good writing". In B. Couture (Ed.), Functional approaches to writing: Research perspectives 241-265). London, Frances Pinter.

Nunan, D. \& Lamb, C. (1996). The self-directed teacher: Managing the learning process. Cambridge: Cambridge University Press.

Nunan, D. (1999). Second language teaching \& learning. Boston: Heinle \& Heinle.

Promwinai, P. (2010). The demands of agumentative essay writing: Experience of Thai tertiary students. Unpublished doctoral dissertation. University of Wollongong, New South Wales.

Richards, J. \& Rodgers, T. (2014). Approaches and Methods in Language Teaching (3rd ed). Cambridge: Cambridge University Press

Swales, J. (1990). Genre analysis. Cambridge: Humans Thinking to Thinking Press Ltd.

Trinh, Q. L. \& Nguyen, T. T. (2014). Enhancing Vietnamese learners' ability in writing argumentative essays. The Journal of ASIA TEFL, 11(2), 63-91.

Tuyen, K. T., Osman, S. B., Thai, C. D. \& Ahmad, N. S. B. (2016). Developing research paper writing programs for EFL/ESL undergraduate students using process genre approach. Higher Education Studies, 6(2),1-29. http://dx.doi.org/10.5539/hes.v6n2p19

Viriya , C. \& Wasanasomsithi, P. (2017). The effect of the genre awareness approach on development of writing ability. International Forum of Teaching and Studies, 13(1), 11 22.

Vygotsky, L. (1978). Mind in society: The development of higher psychological processes. Cambridge, MA: Harvard University Press.

Wang, C. (2013). A study of genre approach in EFL writing. Theory and Practice in Language Studies, 3 (11), 2128-2135. http://dx.doi.org/10.4304/tpls.3.11.2128-21351

Watanabe, H. (2016). Genre analysis of writing tasks in Japanese university entrance examination. Language Testing in Asia, 6(4), 1-14. https://doi.org/10.1186/s40468016-0026-8

Yasuda, S. (2011). Genre-based tasks in foreign language writing: Developing writer's genre awareness, linguistic knowledge, and writing competence. Journal of Second Language Writing, 20(2), 111-133. https://doi.org/10.1016/j.jslw.2011.03.001 


\section{Appendix A}

\section{Pre-Questionnaires}

Please answer the following questions:

1. Which of following types of letter genre have you ever written in Vietnamese?
a. Writing a response to an invitation
b. Writing a response giving advice
c. Writing a complaint letter
d. Writing an opinion letter
e. Writing a letter to editor

2. In which situation did you write the letter?

\begin{tabular}{|l|l|l|}
\hline \multicolumn{2}{|l|}{ Types of letter genre } & Situations \\
\cline { 2 - 3 } & Informal & Formal \\
\hline a. Writing a response to an invitation & & \\
\hline b. Writing a response giving advice & & \\
\hline c. Writing a complaint letter & & \\
\hline d. Writing an opinion letter & & \\
\hline e. Writing a letter to editor & & \\
\hline
\end{tabular}




\section{Appendix B}

Please choose the answers to show your responses to the four stages of the teaching-learning cycle used in your writing class.

\section{Stage 1 Preparing or Building Knowledge of the Field}

1. This stage was... in raising your awareness of the letter type you learn?
$\square$ a. very helpful
$\square$ b. helpful
$\square$ c. not much helpful
d. not helpful

2 . This stage was ... in raising your awareness of the format of the letter type you learn?
$\square$ a. very helpful
$\square$ b. helpful
c. not much helpful
d. not helpful

3. This stage was ... in raising your awareness of the intended readers of the letter type you learn?
$\square$ a. very helpful
$\square$ b. helpful
c. not much helpful
d. not helpful

4. This stage was ... in raising your awareness of the purpose of the letter type you learn?
$\square$ a. very helpful
$\square$ b. helpful
$\square$ c. not much helpful
d. not helpful

5 . This stage was ... in raising your awareness of the context of the letter type you learn?
$\square$ a. very helpful
$\square$ b. helpful
c. not much helpful
d. not helpful

6 . This stage was ... in raising your awareness of the culture-specific features of the letter type you learn?
$\square$ a. very helpful
$\square$ b. helpful
c. not much helpful
d. not helpful

\section{Stage 2 Modelling of Text}

1. Did this stage help you recognize the format of the model letter?
$\square$ a. Yes
$\square$ b. No

2. Did this stage make you aware of the writer and the intended audience of the model letter?
$\square$ a. Yes
$\square$ b. No

3. Did this stage help you distinguish the tone of the model letter?
$\square$ a. Yes
$\square$ b. No

4. Did this stage help you recognize how ideas are organized in the model letter?
$\square$ a. Yes
$\square$ b. No

5. Did this stage enable you to pick up the language features of the model letter?
$\square$ a. Yes
$\square$ b. No

\section{Stage 3 Joint-construction of the Text}

1. Did this stage foster your understanding of features characteristic of the letter type you learn?
$\square$ a. Yes
b. No

2. Did this stage enable you to join writing practice?
$\square$ a. Yes
$\square$ b. No

3. Did this stage provide you useful feedback from the teacher?
$\square$ a. Yes
$\square$ b. No 
4. Did this stage build up your confidence for individual writing?
$\square$ a. Yes
$\square$ b. No

\section{Stage 4 Independent Construction of the Text}

1. Do you understand the requirements of the writing task?
$\square$ a. Yes
$\square$ b. No

2. Are you aware of the intended reader?
$\square$ a. Yes
$\square$ b. No

3. Can you now use the conventional format for the letter type?
$\square$ a. Yes
$\square$ b. No

4. Can you now choose the right tone for the letter?
$\square$ a. Yes
b. No

5. Do you consider the cultural context of the letter?
$\square$ a. Yes
$\neg$ b. No

6. Do you pay attention to the organization of the ideas in the letter?
$\square$ a. Yes
$\square$ b. No

7. Do you consider choosing language resource suitable for the context of the letter?
$\square$ a. Yes
$\square$ b. No 


\section{Appendix C}

\section{Post-Questionnaires}

Please answer the following questions. You can tick more than one option.

1. Which of the following features have you felt improved under the genre-based instruction?
$\square$ a. Context
$\square$ b. Conventions
$\square$ c. Tone
$\square$ d. Organization
e. Grammar
$\square$ g. Vocabulary

2. Which letter type do you think you are able to write successfully after learning?

$\square$ a. Writing a response to an invitation

$\square$ b. Writing a response giving advice

$\square$ c. Writing a complaint letter

$\square$ d. Writing an opinion letter

$\square$ e. Writing a letter to editor 


\section{Test 1}

\section{Appendix D}

Duration: 60 minutes

Word length: 100-120 words for each letter.

\section{Task 1}

You have received a letter from the Youth Club to invite you to a charity event held in your school next week. Write a response to the invitation.

If you are able to participate in the event, accept the invitation and confirm your attendance. Ask if there is anything you need to prepare for the event.

If you are unable to participate in the event, give the reason and ask for joining another event of the club.

\section{Task 2}

Your cousin has been busy preparing for the high school graduation exams. Write a letter giving advice to him/her, sharing your experience.

\section{Test 2}

Duration: 60 minutes

Word length: 120-150 words for each letter

Task 1

You are the freshman and have just become the member of your school English speaking club. However, you find the activities as not interesting as you expect. Write a letter of complaint to the club leader to suggest changes.

\section{Task 2}

Universities in Vietnam are giving a poll to ask for the reform of the subjects in the university entrance exam. As a freshman who just passed the exam, write a letter to editor to express your point of view. 